ISSN: $1412-4734$

E-ISSN: 2407-8646

Volume 18, Number 1, 2018

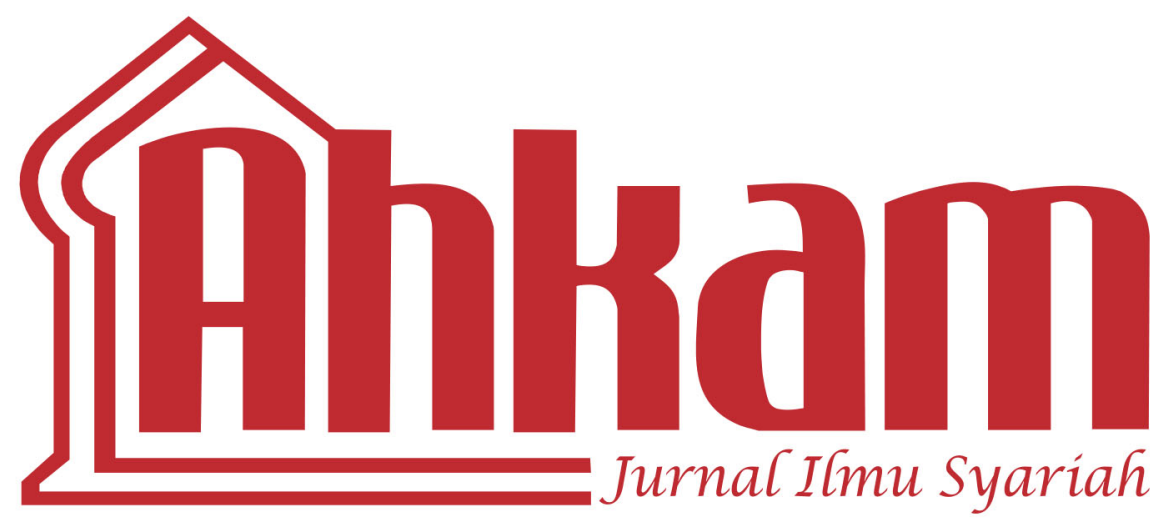

* Herdi Sahrasad \& Al Chaidar

Indonesian Terrorist, ISIS, and Globalization of Terror: A Perspective

* Hotnidah Nasution

Implementation of the Principle of Ultra Petitum Partium in Deciding Children Livelihood in Divorce Lawsuit in Religious Courts

* Havis Aravik, Choiriyah \& Saprida

Critical Study on the Legal Thinking of Muhammad Shahrur

* Nita Triana

Urgency of Arbitration Clause in Determining the Resolution of Sharia Economic Disputes

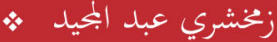

أهمية قوانين المصارف الشرعية في إنلدونيسيا (نظرية التقسير الموضوعى)

* Arrisman

Islamic Law And Business Ethics: Case Study of Forest Fires for Clearing the Lands 


\section{Mhliam}

Volume 18, Number 1, 2018

EDITOR-IN-CHIEF

Khamami Zada

EDITORS

Fathudin

Maman R Hakim

Windy Triana

Nur Hidayah

Ahmad Bahtiar

INTERNATIONAL EDITORIAL BOARD

Tim Lindsey (University of Melbourne Australia)

Nadirsyah Hosen (Monash University Australia)

Ahmad Hidayat Buang (Universiti Malaya Malaysia)

Raihanah Azahari (University Malay Malaysia)

Mark Elwen Cammack (Southwestern University)

Razeen Sappideen (University of Western Sydney)

Carolyn Sappideen (University of Western Sydney)

Nik Ahmad Kamal bin Nik Mahmod (International Islamic Universiti Malaysia)

Ahmad Tholabi Kharlie (UIN Syarif Hidayatullah Jakarta)

Muhammad Atho Mudzhar (UIN Syarif Hidayatullah Jakarta)

Masykuri Abdillah (UIN Syarif Hidayatullah Jakarta)

Muhammad Amin Suma (UIN Syarif Hidayatullah Jakarta)

M. Arsykal Salim GP (UIN Syarif Hidayatullah Jakarta)

Asep Saepudin Jahar (UIN Syarif Hidayatullah Jakarta)

ASSISTANT TO THE EDITORS

Kamal F. Musa

Erwin Hikmatiar

ENGLISH LANGUAGE ADVISOR

Bradley Holland

Umi Kulsum

ARABIC LANGUAGE ADVISOR

Amany Burhanudin Lubis

AHKAM has been accredited based on the determination of Director General of Research Reinforcement and Development, Research, and Technology Ministry of Higher Education of Republic of Indonesia, No. 36/a/E/KPT/2016 (valid until 2021). 
AHKAM Jurnal Ilmu Syariah (ISSN: 1412-4734) is a periodical scientific journal published by Faculty of Sharia and Law of Syarif Hidayatullah State Islamic University Jakarta in collaboration with Indonesian Scientist and Sharia Scholar Association (HISSI). This journal specifically examines the science of sharia and obtains to present various results of current and eminence scientific research. The administrators receive articles as contributions Sharia and Islamic law disciplines from scientists, scholars, professionals, and researchers to be published and disseminated.

\section{EDITORIAL OFFICE:}

Fakultas Syariah dan Hukum UIN Syarif Hidayatullah Jakarta

Jl. Ir. H. Juanda 95 Ciputat, Jakarta 15412

Telp. (+62-21) 74711537, Faks. (+62-21) 7491821

Website: http://journal.uinjkt.ac.id/index.php/ahkam/index

E-mail: Jurnal.ahkam@uinjkt.ac.id 


\section{Table of Contents}

1 Herdi Sahrasad \& Al Chaidar

Indonesian Terrorist, ISIS, and Globalization of Terror:

A Perspective

23 Hotnidah Nasution

Implementation of the Principle of Ultra Petitum Partium in Deciding Children Livelihood in Divorce Lawsuit in Religious Courts

43 Havis Aravik, Choiriyah \& Saprida

Critical Study on The Legal Thinking of Muhammad Shahrur

65 Nita Triana

Urgency of Arbitration Clause in Determining The Resolution of Sharia Economic Disputes

89

زخشري عبد المجيد

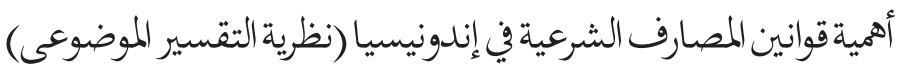


109 Arrisman

Islamic Law and Business Ethics: Case Study of Forest Fires for Clearing The Lands

125 Abdulmajeed Hassan-Bello

Riba and Islamic Banking, Examining the Practices of Jaiz Bank PLC, Nigeria

155 ISNaWATI Rais

Marriage Dispensation due to Extramarital Pregnancy: The Study on the Decision by the Religious Court of South Jakarta (2010-2011)

177 HaMZAH

Zakah Empowerment Optimization Through Baitul Ikhtiar Cooperation as an Effort in Poverty Alleviation in Bogor Regency

201 Abdul Muta'Ali

Israel and Palestine Conflict from Linguistics and Figh

Siyasah Perspective

219 Susiknan Azhari

Tracing the Concept of Fajr in the Islam Mosaic and Modern Science

233 Ahmad Sholihin Siregar

The Construction of Āyātul Aḥkām (Constructing the Selection Bases of Āyātul Aḅkàm) 


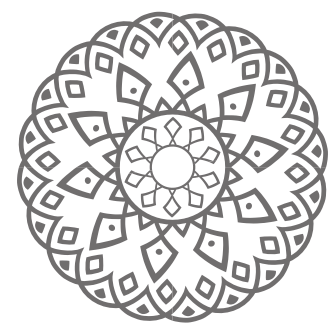

\title{
Marriage Dispensation due to Extramarital Pregnancy: The Study on the Decision by the Religious Court of SOUTH JAKARTA (2OIO-2O I I)
}

\section{Isnawati Rais}

\begin{abstract}
Abstrak: Tulisan ini memfokuskan pada putusan hukum dan pertimbangan hakim dalam menetapkan permohonan dispensasi nikah di Pengadilan Agama Jakarta Selatan akibat hamil di luar nikah. Tulisan ini berdasarkan kajian terhadap tiga penetapan di pengadilan tersebut yaitu Nomor: 056/Pdt.P/2010/ PA.JS., Penetapan Nomor: 219/Pdt.P/2011/PA.JS dan Penetapan Nomor: 197/ Pdt.P/2011/PA.JS yang ketiganya mengabulkan permohonan dispensasi nikah akibat hamil di luar nikah. Berdasarkan kajian itu, peneliti menemukan bahwa pengabulan permohonan dispensasi nikah di Pengadilan Agama Jakarta Selatan karena hamil di luar nikah oleh Majelis Hakim didasarkan pada argumen menghindari kemudaratan dan tidak dilanggarnya peraturan yang ada. Hal ini menunjukkan bahwa pertimbangan hakim dalam menetapkan dispenasi nikah untuk kasus hamil di luar nikah tidak sekadar mendasarkan pada ketentuan pasal 7 ayat (2) Undang-Undang Nomor 1 tahun 1974 tentang Perkawinan jo. Pasal 15 ayat (2) Kompilasi Hukum Islam akan kemudaratan jika permohonanan dispensasi nikahnya ditolak. Dalam penentuan pertimbangan kemudaratan, tampak Majelis Hakim dipengaruhi oleh pandangan keagamaan dan akibat sosial yang ditimbulkan jika tidak diberi dispensasi nikah.
\end{abstract}

Kata kunci: dispensasi perkawinan, hamil di luar nikah, pengadilan agama 
Abstract: The Marriage law in Indonesia sets the marriageable age at which a person is allowed to marry is 19 (nineteen) years old for men and 16 (sixteen) years old for women. This study focuses on legal decisions and judges' consideration in establishing the application for marriage dispensation at the Religious Court of South Jakarta due to extramarital pregnancy. This study shows that the Court decision to grant the application for marriage dispensation at the Religious Court due to extramarital pregnancy is primarily based on the argument to avoid harmfulness. Using case study research, three court decisions stipulated by the Religious Court Decision Number: 056/Pdt.P/2010/PA.JS, Decision Number: 219/Pdt.P/2011/PA.JS and Decision Number: 197/Pdt.P/2011/PA granting the application for marriage dispensation due to extramarital pregnancy were analysed. The legal consideration formulated by the Panel of Judges is to avoid harm and is not contrary to the legislation. This means the judge's consideration in determining the marriage dispensation due to extramarital pregnancy is not only based on the provisions stated in Article 7 paragraph (2) of the Law No. 1/1974 concerning Marriage jo. Article 15 paragraph (2) of the Compilation of the Islamic Law, but also on the consideration made by the Panel of Judges as the harms might occur if the application for marriage dispensation is refused. In determining this consideration of harms, it appears that they are influenced by their religious views and the social consequences.

Keywords: the marriage law, extramarital pregnancy, Religious Court

$$
\begin{aligned}
& \text { ملخص: يحدد قانون الزواج في إندونيسيا سن الزواج الذي يُسمح فيه للزواج من } 9 \text { المنة سنة للرجال }
\end{aligned}
$$

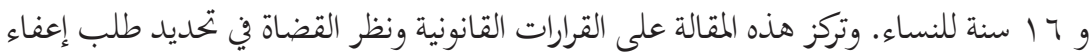

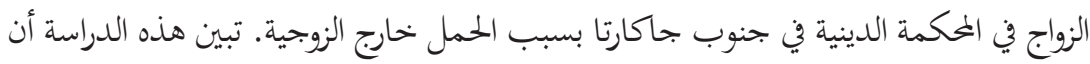

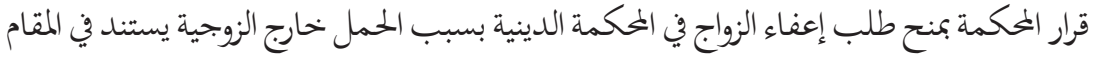

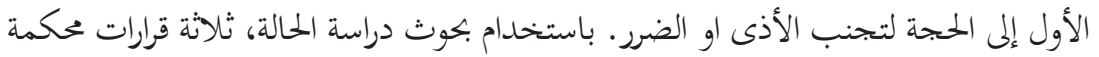

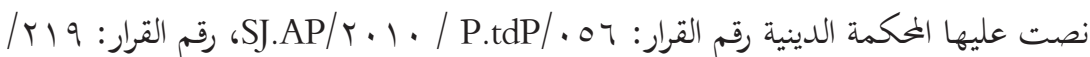

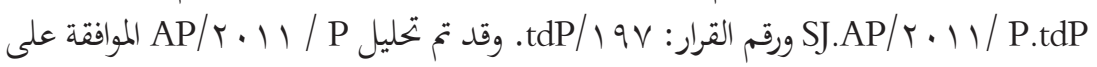

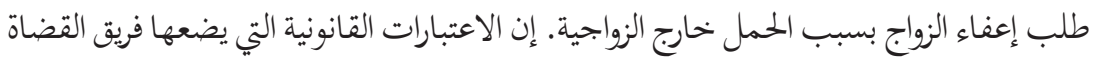

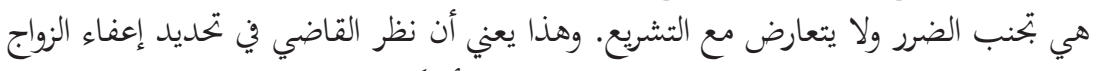

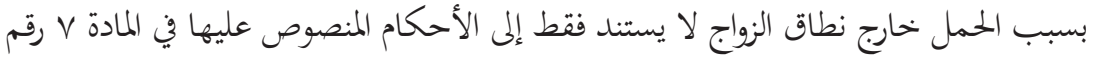

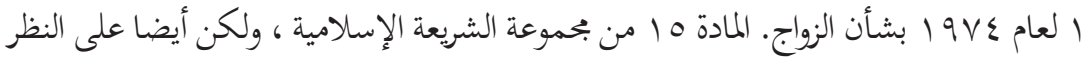

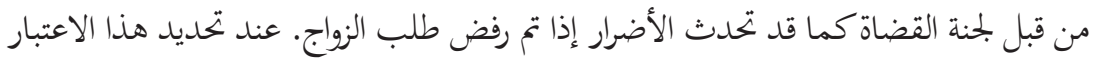

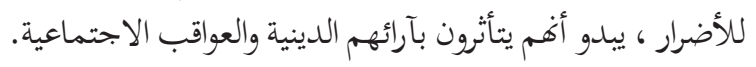$$
\text { الكلمات المفتاحية: قانون الزواج، الحمل خارج الزوجية، المحكمة الدينية }
$$ 


\section{Introduction}

The marriageable age set in the Marriage Law does not seem to reflect the level of maturity for those who are willing to get married. The minimum age of consent for marriage mentioned in Article 7 paragraph (1) of the Law No. 1/1974 and Article 15 paragraph (2) of the Compilation of the Islamic Law does not stipulate that they must considered adults and capable of dealing with their own life and marriage. This consent only shows the age at which they are allowed to marry. This can be seen from the provisions set in article 6 paragraph (2) of the Law No. 1/1974, stating that a person may get married without requiring parental permission if he/she is 21 years old. In the same way, it is stipulated that "to get married, a person who has not reached the age of 21 (twenty one) years must seek for permission from both parents".

In the meantime, Article 15 paragraph (2) of the Compilation of Islamic Law also mentions "Those who have not reached the age of 21 years must obtain permission as stipulated in article 6 paragraph (2), (3), (4) and (5) of the Law no. 1/1974". The aforementioned provisions set in the Law No. 1 and the Compilation of Islamic Law confirm that a person is finally considered as an adult and capable of dealing with his/her own marriage if he/she is 21 years old. However, those who have not reached the age of 21 years must get permission from both parents, while those who are less than 19 years old and 16 years old must be granted dispensation by the Court.

Article 7 paragraph (1) of the Law No. 1/1974 on Marriage and the Compilation of Islamic Law illustrate the objectives and benefits of restricting the marriageable age. In article 15 paragraph (1) of the Compilation of Islamic Law, for example, mentions: "for the sake of family and household, marriage can only happen for those who have reached the age specified in article 7 of the Law No. 1/1974. Here, the man is at least 19 years old and the woman is 6 years old. "However, the marriage law also gives marriage dispensation for men and women under the minimum age of consent after meeting the criteria required by the Religious Court".

In fact, many people are willing to get married under the minimum age of consent. It is seen from the data regarding the application of 
marriage dispensation in various Religious Courts in Indonesia, in which the number is very surprising and even shows a significant increase every year. At the national level, the data derived from the Directorate General of the Religious Courts Body (Direktorat Jenderal Badan Peradilan Agama/Badilag), the Republic of Indonesia mention the number of marriage dispensation cases and other cases received by the Provincial Court/Religious High Court throughout Indonesia from 2009 to 2012 is quite high.

Table 1. Data on the number of marriage dispensation cases and other cases In 2009-2012

\begin{tabular}{|c|c|c|c|c|c|c|}
\hline \multirow{2}{*}{ No. } & \multirow[t]{2}{*}{ Case } & \multicolumn{4}{|c|}{ Year } & \multirow{2}{*}{ Total } \\
\hline & & 2009 & 2010 & 2011 & 2012 & \\
\hline 1. & $\begin{array}{c}\text { Marriage } \\
\text { Dispensation }\end{array}$ & 1209 & 2933 & 5518 & 9540 & 19200 \\
\hline 2. & Other Cases & 72732 & 151760 & 246686 & 382113 & 853291 \\
\hline & Total & 73941 & 154693 & 252204 & 391653 & 872491 \\
\hline
\end{tabular}

Source: the Directorate General of the Religious Courts Body

Judging from the annual increase, the marriage dispensation has experienced a significant increase every year. In 2009, for example, the number of Marriage Dispensation cases was about 1,209 cases, while it rose to 2,933 cases in 2010 . This means the difference of the number of the cases in 2009 and 2010 is equal to 1,724 cases or it is said the number of the cases increases to $59 \%$. Compared to the cases in 2010, those in 2011 reach 5,518 cases. The number shows a difference of 2,585 cases in both years which is equal to $47 \%$. At last, the increase from 2011 to 2012 reaches $42 \%$, from 5,518 cases to 9,540 cases, with a difference of 4,022 cases.

Basically, the factors affecting a person to apply for marriage dispensation vary. These factors also differ between rural and urban areas. In rural areas, for example, a person applies for marriage dispensation due to the low level of education and cultural factors. Here, extramarital pregnancy is not significant. On the contrary, in urban 
areas, the dominant factor is extramarital pregnancy in which both persons have had intense sexual intercourse. The marriage dispensation due to cultural factors as rural pehenomenon at the Religious Court of South Jakarta is rare.

The phenomenon of the increasing number in marriage dispensation cases also occurs at the Religious Court of South Jakarta. Such number has increased every year. In 2010, for example, 3 cases of marriage dispensation were recorded. In the following year, 8 cases were found, while 8 cases occurred in 2012 as illustrated in the following table:

Table 2. Number of Marriage Dispensation Cases at the Religious Courts of Jakarta

\begin{tabular}{|lcccc|}
\hline Religious Court & $\mathbf{2 0 1 0}$ & $\mathbf{2 0 1 1}$ & $\mathbf{2 0 1 2}$ & Total \\
\hline West Jakarta & 1 & 6 & 6 & $\mathbf{1 3}$ \\
\hline Central Jakarta & 2 & 3 & 8 & $\mathbf{1 3}$ \\
\hline South Jakarta & 3 & 8 & 8 & $\mathbf{1 9}$ \\
\hline East Jakarta & 2 & 10 & 14 & $\mathbf{2 6}$ \\
\hline North Jakarta & 1 & 3 & 6 & $\mathbf{1 0}$ \\
\hline Total & 9 & 30 & 42 & 81 \\
\hline
\end{tabular}

Source: infoperkara.badilag.net

The extramarital pregnancy mainly triggers the increasing cases of marriage dispensation. This means free sex has become a major problem that results in extramarital pregnancy which in turn increases the number of marriage dispensation. This can be seen from a number of cases regarding the application of marriage dispensation at the Religious Court of South Jakarta, most of which is caused by extramarital pregnancy.

The significant increase on the application of marriage dispensation cases that have been decided by the Religious Courts is considered as social and legal phenomena about what constitutes the factors a person applies for marriage dispensation and what is considered 
by the Judges at the Religious Court of South Jakarta in granting or rejecting the application. These cases are examined in qualitative research with a case study approach. For this reason, this study focuses on the judge's decisions and considerations in deciding the marriage dispensation cases at the Religious Court of South Jakarta, specifically the Provision Number: 056/Pdt.P/2010/PA.JS which is categorized as underage marriage. Further, Provision Number: 219/Pdt.P/2011/ PA.JS deals with underage husband-to-be, while Provision Number: 197/Pdt.P/2011/PA.JS focuses on underage wife-to-be.

\section{Judge's Provisions in Marriage Dispensation}

The Religious Court of South Jakarta has stipulated marriage dispensation through Provision Number: 056/Pdt.P/2010/PA.JS., Provision Number: 219/Pdt.P/2011/PA.JS and Provision Number: 197/Pdt.P/2011/PA.JS. These three provisions focus on the application of marriage dispensation in the case of underage marriage, underage husband-to-be, and underage wife-to-be.

First, the marriage dispensation is granted in the case of underage marriage under the Provision Number: 056/Pdt.P/2010/PA.JS. On April 13, 2010, the Religious Court of South Jakarta granted the application of marriage dispensation case filed by a parent of a child residing in Bali Matraman RT 007/RW 006, Manggarai Selatan, Tebet, South Jakarta as Applicant I and another parent of a child living at jalan Menteng Rawa Panjang RT 002/RW 015 No. 15 Menteng Atas, Setiabudi, South Jakarta as Applicant II registered at the Religious Court of South Jakarta with registration number 0056/Pdt.P/2010/ PA.JS.

In term of positive law, it is stated that the applicant I has a son named AJ who is 16 years and 10 months old, while the applicant II has a 15-year and 10-month-old daughter named RA. Both intend to get married. The reason of both applicants to marry off AJ and RA immediately is that both of them have established relationship and have had sexual intercourse outside of marriage and RA is currently in a 3 (three) month pregnancy. As a sense of responsibility, AJ has proposed to RA and the proposal has been granted by the applicant II. To deal with the marriage process, both applicants have registered the marriage plan to the Religious Affairs Office of Setiabudi, South 
Jakarta, but the Office has refused to marry them off as they have not met the minimum age of consent for marriage, a 19-year-old man and a 16-year-old woman. Here, the husband-to-be is only 16 years and 10 months old, while the wife-to-be is 15 years and 10 months old. Both AJ and RA do not have any illicit relationship for them to get married. Referring to the aforementioned difficulties, the applicants have then submitted the application of marriage dispensation to the Religious Court of South Jakarta.

Regarding the petitum law, the applicants request the Chairperson of the Religious Court of South Jakarta c.q. the Panel of Judges to pleasantly open the trial to stipulate AJ's marriage dispensation to marry RA and demand the Head of the Religious Affairs Office of Setiabudi, South Jakarta, to register AJ's marriage with RA.

To confirm the arguments of the petition, the applicants who have now become petitioners have submitted evidence, in the form of legitimate stamped copy of the Marriage Certificate number 190/83/V/1984 issued by the Head of Religious Affairs Office of Setiabudi, South Jakarta on May 18, 1984 (Exhibit P-1), a legally stamped copy of origin certificate issued by the Village Head of South Manggarai on March 30, 2010 (Exhibit P-2), Legitimate stamped copy of birth certificate under the name of AJ Number 10255/U/JS/1993 issued by the Head of Civil Registry Office of South Jakarta on June 23, 1993 (Exhibit P-3), a legally stamped copy of letter of statement issued by the Village Head of South Manggarai on March 30, 2010 (Exhibit P-4), a legitimate stamped copy of marriage certificate issued by the Village Head of South Manggarai on March 30, 2010 (Exhibit P-5), a legitimate stamped copy of marriage will from the Religious Affairs Office of Tebet addressed to the Head of the Religious Affairs Office of Setiabudi on March 30, 2010 (Exhibit P-6), a legitimate stamped copy of statement made and signed by AJ on March 29, 2010 (Exhibit P-7), a copy of statement of marriage to have never got married made and signed by RA on March 30, 2010 (Exhibit P-8), and a valid stamped copy of Birth Certificate on behalf of RA issued by the Head of the Civil Registry Implementation Unit of South Jakarta on June 8, 1994 (Exhibit P-9).

The Petitioners have also presented witnesses who have given testimony under their oath. The first witness who is the neighbor of 
the petitioners mention the relationship between $\mathrm{AJ}$ and RA has gone too far which has caused a 3 (three) months pregnancy. At their age, AJ with RA are not eligible to get married as they are underage according to the law. Both AJ and RA are singles and neither bound by marriage to another person nor muhrim (an unmarriageable kin with whom marriage or sexual intercourse would be considered haram, illegal in Islam). In addition, the families of both have agreed to marry off AJ and RA. Like the first witness, the second witness who is the Petitioner I's brother-in-law state that both Petitioners are willing to marry off AJ and RA as RA is 3 (three) months pregnant. They are neither bound by blood nor married to another person and the petitioners have agreed to marry them off.

After the trial, the panel of judges has finally granted the petitioners' petition by giving a marriage dispensation permit to AJ with RA. This decision was handed down by the Panel of Judges comprised of $\mathrm{MH}$ as the Presiding Judge and MK and TM as the Member Judges, along with $\mathrm{NH}$ as the Substitute Registrar on Tuesday, May 4, 2010 coinciding with the 19th of Jumadil Awwal 1431 in Islamic calendar.

The legal consideration taken by the panel of judges is based on the fact that $\mathrm{AJ}$ (16 years and 10 months old) and RA (15 years and 10 months old) have maintained a very close relationship and are hard to part away, especially after RA is in 3 month pregnancy. They both are willing to get married. Here, both of them are single and not bound by family relationship (mahram). Practically, the Judges have also advised them to avoid marriage at a young age, but it did not work.

Due to the fact that AJ and RA are not old enough to get married, but they have established very intimate relationships, the Panel of Judges think to consider the petitioners' petition to marry off their children to avoid more harms and for the benefit of family. The Panel has then stated that the petition is in accordance with the provisions in article 7 paragraph (2) of the Law No. 1/1974 regarding Marriage jo. article 15 paragraph (2) of the Compilation of Islamic Law. Therefore, the petition has met the requirements to be granted. In the end, the Panel may stipulate to grant marriage dispensation to the petitioners in order to marry off AJ and RA. 
Second, the marriage dispensation is given in the case of underage husband-to-be under Provision Number 219/Pdt.P/2011/PA.JS. The Religious Court of South Jakarta has dropped the provision concerning the application of marriage dispensation filed by RD, a 56 year old Muslim who works as a Private Employee and lives at Jl. Swadaya I RT 01/RW 08 Manggarai, Tebet, South Jakarta as applicant registered at the Religious Court of South Jakarta office with registry Number 219/ Pdt.P/2011/PA.JS. on November 18, 2011.

In the case of positive law, the applicant states that he has a 17 year-old son named AC and is willing to marry him off to a 19-year old Muslim woman named GH. She is an employee in a private company and lives at Jalan Keselamatan I RT 07 RW 01, South Manggarai, Tebet, South Jakarta. The reason the Petitioner is willing to immediately marry them off is because both of them have established relationship and have had sexual intercourse outside of marriage. Consequently, $\mathrm{GH}$ is in a 3 (three) month pregnancy. As a sense of responsibility, AC has proposed to $\mathrm{GH}$ and the proposal has been granted. To smoothen the marriage process, the applicant has registered their marriage plan to the Religious Affairs Office of Tebet, South Jakarta, but the Office has refused to marry them both as $\mathrm{AC}$ has not met the minimum marriage age (19 years old). He is only 17 years old. In addition, the applicant has also stated no illicit relationship has happened between AC and GH for both of them to get married. With this statement, the applicant has then submitted the application of marriage dispensation to the Religious Court of South Jakarta. In term of the petitum law, the applicant as the petitioner has requested the Chairperson of the Religious Court of South Jakarta c.q. the Panel of Judges to pleasantly open the trial to provide marriage dispensation to the Petitioner to marry off $\mathrm{AC}$ and $\mathrm{GH}$.

The Petitioner was present personally at the trial. However, the Panel of Judges has advised that the marriage should be postponed until $\mathrm{AC}$ has met the minimum age of consent for marriage. Such attempt was unsuccessful and the Petitioner has remained on his petition until the Panel has granted the marriage dispensation for his son who has not met the marriageable age.

Therefore, to clarify this case, the Panel of Judges has heard the statements of the parties concerned. The Petitioner's son (AC), for 
example, has explained that he would marry GH on the basis of mutual love. No pressure or coercion from anyone occurs as they love each other. $\mathrm{GH}$ is even 3 (three) month pregnant. He adds that he has worked at Catering company with monthly salary of Rp. 1,500,000 (one million and five hundred thousand rupiah). According to the religious law, he also states that his is not family to his wife-to-be and don't find any obstacles to get married. As for the wife-to-be $(\mathrm{GH})$, she clarifies that she would marry AC under her own will and no one has forced her to do so. However, the marriage plan was rejected by the Religious Affairs Office of Tebet, South Jakarta as AC is only 17 years and 8 months old. She further mentions AC's parents have already proposed to her and her parents have agreed.

To confirm the arguments of the petition, the Petitioner has submitted some documents as evidence such as a copy of family certificate under the name of RD No. 3174010501093591 dated July 16, 2011 and issued by the Lurah of Manggarai Village, Tebet, South Jakarta (Exhibit P-1), a copy of an ID card under the name of RD No. 09.5301.080555.0026 dated May 19, 2008 and issued by the Lurah of Manggarai Village, Tebet, South Jakarta (Exhibit P-2), and a copy of an ID card under the name of AC No. 3174012203940004 dated April 4, 2011 and issued by the Lurah of Manggarai Village, Tebet, South Jakarta (Exhibit P-3). In addition to the evidence, the Petitioner has also presented witnesses from the family who have shown their concerns and allowed the marriage.

After the trial, on one side, the Panel of Judges has come to a decision considering that the petitioner was present personally at the trial and the Panel has given advice and consideration, but it was not successful as the Petitioner has remained on his petition. On another side, the bigger concern in this case is the Petitioner has requested that his son, AC who was born on March 22, 1994 would be granted a dispensation to marry a woman of his choice named GH due to her 3 (three) month pregnancy, but the Religious Affairs Office has refused to marry them off.

Referring to the Petitioners' statement, AC, GH, documents and witnesses, the following legal facts are found: (1) The Petitioner has a son named AC who was born on March 22, 1994, (2) the Petitioner's child has a relationship with a woman named GH and she is in 3 (three) 
month pregnancy, (3) $\mathrm{AC}$ has proposed to $\mathrm{GH}$ and the proposal has been granted, (4) both $\mathrm{AC}$ and $\mathrm{GH}$ are not bound by blood or any kinship that prevents them to get married, and (5) the Petitioner has submitted an application to the Marriage Registration Officer to process $\mathrm{AC}$ and GH's marriage, but the Officer has rejected the application on the grounds that the husband-to-be (AC) has not fulfilled the minimum age of consent for marriage as stipulated in the Law.

Based on the legal facts in the trial, the Panel of Judges has come to a consideration that it is suspected to lead to a greater harm if the action to marry off Petitioner's son (AC) and GH is not immediately taken, especially if both have love each other and both mentally and materially are ready to face all risks in their household. Based on these considerations, the Panel of Judges has eventually given a dispensation to the Petitioner to marry off his son named AC and GH as stipulated in article 7 paragraph (2) of the Law Number 1/1974 concerning Marriage. This provision was enacted by the Religious Court of South Jakarta including NH as the presiding judge and NS and LD as Member Judges on Wednesday, December 21, 2011 (the 25 th of Shafar 1433 in Islamic calendar). It was pronounced in a court session publicly by the Chairperson of the Session and attended by the Member Judges, along with AN as the Substitute Registrar in the presence of the petitioner.

Third, marriage dispensation is granted in the case of underage wife-to-be under the provision Number 197/Pdt.P/2011/PA.JS. The Religious Court of South Jakarta has dropped the provision regarding the application for marriage dispensation filed by ZK, a 47 year old Muslim who works as Private Employee and lives at jalan Cikoko Barat IV No. 26 RT. 04/05, Cikoko, Pancoran, South Jakarta on October 18, 2011 and registered at the Religious Court of South Jakarta with registry number 197/Pdt.P/2011/PA.JS. on October 18, 2011.

In terms of positive law, the applicant mentions to have a 14 year old daughter named $\mathrm{KN}$ and intends to marry off her daughter to a 21 year old Muslim man named DR and works as a Private Employee and lives at jalan Sahid Gg. I No. 31 RT. 04/01 Pejaten Barat, Pasar Minggu, South Jakarta. The reason the applicant is willing to immediately marry them off is because both of them have established relationship and have had sexual intercourse outside of marriage which consequently 
has caused pregnancy. As a sense of responsibility, DR has proposed to $\mathrm{KN}$ and the proposal has been accepted. To process the marriage, the applicant has registered their marriage plan to the Religious Affairs Office of Pancoran, South Jakarta, but the Office has declined to marry them off considering $\mathrm{KN}$ has not reached the minimum age of consent for marriage (16 years old). She was 14 years old at the time she registered. The applicant also mentions no illicit relationship has happened between KN and DR to prevent them to get married. Referring to statement, the applicant has submitted the application for marriage dispensation to the Religious Court of South Jakarta. Regarding the petitum law, the applicant who is in turn regarded as petitioner has requested the Chairperson of the Religious Court of South Jakarta c.q. the Panel of Judges to open the trial to grant the marriage dispensation to marry off $\mathrm{KN}$ and DR.

In the trial, the Petitioner was present personally. The Panel of Judges has also sought to provide advice so that the Petitioner's marriage could be postponed until $\mathrm{KN}$ has finally met the minimum standard of marriageable age. However, the attempt was unsuccessful and the Petitioner has remained on his petition to marry off his underage daughter.

To clarify this case, the Panel of Judges has heard the statements of the parties concerned. The Petitioner's daughter $(\mathrm{KN})$ explains that she would marry DR for love. However, she is not yet 16 years old as required by the law. She is only 14 years old and her husbandto-be is 21 years old. However, both have done a husband and wife relationship which has caused her pregnancy. In addition, she adds that she has already quitted school and is ready to live with his husband-to-be and accept his situation. She further explains that they are not bound by blood or kinship with her husband-to-be. In the meantime, DR mentions that he is willing to marry $\mathrm{KN}$, however his willingness is rejected by the Religious Affairs Office of Pancoran, South Jakarta considering $\mathrm{KN}$ is not old enough to get married and she is only 14 years old, even though he has had sexual intercourse which has cause $\mathrm{KN}$ to be pregnant. He also states that he would marry her with no coercion from anyone's family and earn monthly income of Rp. 1,200,000, - (one million and two hundred thousand rupiah) for his family-to-be. 
To confirm the arguments of the petition, the Petitioner has submitted documents as evidence, such as a copy of family card under the name of ZK No. 3174082612100021 issued by Pancoran Subdistrict, South Jakarta (Exhibit P-1), a copy of Birth Certificate under the name of KN No. 9569/U/JS/1997 issued by the Head of Civil Registry Office of South Jakarta (Exhibit P-2), a Copy of family card under the name of RM No. 3174040501090240 issued by Pasar Minggu Subdistrict, South Jakarta (Exhibit P-3), and Copy of Birth Certificate under the name of DR No. 14472/JS/1990 issued by the Head of Civil Registry Office of South Jakarta (Exhibit P-4).

The present witnesses include RM as the father of the husband-tobe and ML as the Petitioner's neighbor. They explain that DR and KN would get married, but it was rejected by the Religious Affairs Office of Pencoran, South Jakarta considering the marriageable age of a woman to get married is 16 years old as required by the legislation and $\mathrm{KN}$ was only 14 years old at the time they applied their marriage. Both add that they are not bound by blood and they have made a husband and wife relationship which has consequently caused KN's pregnancy. In addition, in their statement, they mention DR has already worked and is able to deal with the family economy.

In the trial, on one side, the Panel of Judges has come to a decision considering that the petitioner was present personally at the trial and the Panel has given advice and consideration, but it was not successful as the Petitioner has remained on his petition. On another side, the bigger concern in this case is the Petitioner has requested that his daughter, $\mathrm{KN}$ who was born on April 06, 1997 would be granted a dispensation to marry a man of her choice named DR due to her pregnancy, but the Religious Affairs Office has refused to marry them off.

Based on the statements of the Petitioner, KN, DR, documents, and witnesses, the legal facts are as follows: (1) The Petitioner has a daughter named KN who was born on April 6, 1997, (2) the Petitioner's daughter has a relationship with a man named DR, and her relationship has caused her pregnancy, (3) DR has proposed to KN and the proposal has been accepted by the Petitioner, (4) KN and DR are not bound by blood or any kinship that prevents a second marriage, and (5) the Petitioner has submitted an application to the Marriage Registration Officer to process DR and KN's marriage, but the Officer 
has rejected the application on the grounds that the wife-to-be (KN) has not fulfilled the minimum age of consent for marriage as stipulated in the Law.

Referring to the legal facts in the trial, the Panel of Judges has come to a consideration that it is suspected to lead to a greater harm if the action to marry off Petitioner's daugther $(\mathrm{KN})$ and $\mathrm{DR}$ is not immediately taken, especially if both have love each other and both mentally and materially are ready to face all risks in their household. Based on these considerations, the Panel of Judges has come to a conclusion that the petition is in accordance with the provision in article 7 paragraph (2) of the Law Number 1/1974 concerning Marriage. As the result, it has met the requirements to be granted, given a dispensation to the Petitioner to marry off his daughter $\mathrm{KN}$ and $\mathrm{DR}$.

As illustrated above, the Panel of Judges always makes considerations in determining marriage dispensation. In the case of marriage dispensation at the Religious Court of South Jakarta, two main considerations are found, legal considerations and considerations of benefit/harm in Provision Number: 056/Pdt.P/2010/PA.JS., Provision Number: 219/Pdt.P/2011/PA.JS. and Provision Number: 197/Pdt.P/2011/PA.JS. These two considerations are often referred to by the Panel of Judges in this region.

\section{Legal Considerations}

Basically, one can apply for a marriage dispensation as stipulated in the Marriage Law article 7 paragraph (2). The applicant is also given independence or freedom to include the reasons in his application, because the law does not specify the reasons for filing the application for marriage dispensation as in filing a petition for a divorce case. Therefore, the articles related to marriage dispensation are essentially emergency articles as certain situations and conditions compel someone to apply for marriage dispensation (Interview with Agus Yunih, 2013). In other words, marriage dispensation is a legal exception (Interview with Rusydi Thahir, 2013).

In establishing the marriage dispensation, the Panel of Judges makes considerations if an application is granted or rejected. The main consideration in such dispensation is an emergency factor 
(interview with Agus Yunih, Maslihan Saifurrozi, and Habibuddin). In the legal aspect, the Panel will examine in the trial if the person who has filed the case for dispensation has the right to file or not. During the trial, the Panel will ask the reason from the applicant's son or daughter and in turn examine it to fit the descriptions both have shared.

Normatively, the Panel of Judges will also examine any marriage ban as stipulated in the Marriage Law article 8 stating a marriage is prohibited between two people who are blood-related in a straight downward or upward lineage, blood-related in a sideway lineage (parents and grandparents' siblings), marriage relationship (parentsin-law, stepchildren, son/daughter-in-law and stepfather/mother), breastfeeding relationship (breastfeeding parents, breastfed children, breastfed mates, and aunts/uncles from the breastfeeding parents), wife-related (wife's siblings, an aunt or niece of the wife), kinship in the case a husband has more than one wife, or any kinship which is prohibited from marrying by religion or other applicable regulations.

The Presidential Instruction No. 1/1991 on the Compilation of Islamic Law article 39 prohibits marriage between a man and a woman due to affinity of nasab (a woman who gave birth or her offspring, a woman from father or mother's descent), because of the affinity of marriage (a woman who gave birth to the wife or ex-wife, a woman who is related to the wife or ex-wife, except the marriage is annulled before having intercourse (qobla al-dukhul), a woman of the wife's offspring), affinity of breastfeeding (women who breastfed and so on in an upward lineage, a woman related due to breastfeeding and so on in a downward lineage, the sisters of the woman related due to breastfeeding, the nephews or nieces of the woman related due to breastfeeding and alike).

Article 40 of the Compilation of Islamic Law, for example, prohibits marriage between a man and a woman due certain circumstances, such as the state where a woman is still bound by a marriage with another man, a woman who is still in the iddah (waiting) period with another man, or a woman who is not Muslim. Article 41 adds that a man is prohibited from marrying a woman who has affinity of nasab or sexual relations with his wife, sibling, father, or mother and offspring, or a woman with her aunt or niece. The prohibition still applies even though 
his wives have been subjected to talaq raji (a revocable form of Talaq), but they are in iddah period (period of waiting for a woman).

In the meantime, Article 42 of The Compilation of Islamic Law also states that a man is prohibited from marrying a woman if he is having 4 (four) wives in which four of whom are still bound by marriage with him or still in the iddah period of talaq raji or one of them is still bound by marriage during the iddah period. In addition, Article 43 of the Compilation of Islamic Law mentions a marriage between a man and his ex-wife was subjected to three time divorce or his ex-wife who was subjected to lian is forbidden. In this case, the prohibition is annulled if the ex-wife has married another man and got divorced after some sexual intercourse (dukhul) and finished her iddah period. At last, Article 44 states that an Islamic woman is prohibited from marrying a man who is not Muslim.

In the case of the provision of marriage dispensation at the Religious Court of South Jakarta in Provision Number: 056/Pdt.P/2010/PA.JS., Provision Number: 219/Pdt.P/2011/PA.JS and Provision Number: 197/Pdt.P/2011/PA.JS, legal considerations formulated by the Panel of Judges in overturning their provision refer to the arguments and legal evidence submitted at the trial. The evidence presented in the three cases of marriage dispensation is based on some legal documents such as Application Letter, a copy of marriage certificate of the parent of the applicant which is stamped with a 6,000 stamp duty at the Post Office, statement letter from the Head of the local Religious Affairs Office stating the rejection due to underage (Model N-9), a copy of Birth Certificate of the prospective bride and groom or a copy of the latest educational certificate stamped under a 6,000 duty stamp at the Post Office, and statement letter of poorness from the Head of Village which is acknowledged by the Head of District for those who are unable to pay the down payment of fees (prodeo). Here, the application for marriage dispensation is submitted by both parents to the Religious Court representing the place their residence. (Ministry of Religion regulations, Number. 3/1975 Article 13 paragraph 2). In addition, other evidence is also presented at the trial, namely fact witnesses from family and neighbors.

The provision stipulated by the Panel of Judges does not contradict to the provisions of the Marriage Law which does not specifically 
address the marriage dispensation and the Compilation of Islamic Law which implicitly does not prohibit the marriage of two people who have had an extramarital relationship. This is mentioned in article 53 of the Compilation of Islamic Law stating a woman with extramarital pregnancy can marry the man who has impregnated her. Further, a marriage with a pregnant woman can be carried out without the need to wait for her to give birth. With the marriage at the time of pregnancy, no marriage is required after the child is born. Thus, the main reason which is considered by the Panel of Judges in deciding or establishing marriage dispensation is the law for legal certainty (interview with Athiroh Muchtar, 2013).

\section{Harm Reduction Considerations}

Basically, the law aims at promoting public interest and avoiding harms. In the case of the provision of marriage dispensation at the Religious Court of South Jakarta, the Provision Number: 056/ Pdt.P/2010/PA.JS., Provision Number: 219/Pdt.P/2011/PA.JS and Provision Number: 197/Pdt.P/2011/PA.JS. seem to allow the Panel of Judges to grant the marriage dispensation filed by the Petitioner to marry off his son/daughter considering that it would lead to a greater harm if the two parties do not immediately get married. This consideration is recognized by one of the judges at the Religious Court of South Jakarta, Athiroh Muchtar and almost no judges reject the application for marriage dispensation by reason of preventing harms (interview with Agus Yunih, 2013). In other words, the Religious Court has granted a marriage dispensation fearing that it would lead to another sin and an underhanded marriage which would disrupt the legal processes that would occur in the next phase or disrupt the legal rights of the child born according to the law. In addition, the community will insult and isolate women who are pregnant without husbands.

This consideration is based on Islamic norms, which is the content of Surah An-Nur [24] verse 3: "The fornicator does not marry except a female fornicator or polytheist, and none marries her except a fornicator or a polytheist, and that has been made unlawful to the believers", and Surah an-Nur [24] verse 32. "And marry the unmarried among you and the righteous among your male slaves and female slaves. If they should be poor, 
Allah will enrich them from His bounty, and Allah is all-Encompassing and Knowing."

Men who do not act naturally do not want to marry pious women. Likewise, women who commit fornication won't be married by a righteous man. This is a common law, but this does not give an understanding that fornicators are not allowed to marry women who are righteous and also does not mean that all female fornicator should not be married by a righteous man.

The above surah does not mean that male fornicators cannot marry other than female fornicators (Sayyid Sabiq, 1992: 87-88) or that the state in which female fornicators are married to men who do not commit adultery is illegitimate. However, the verse was revealed to prevent the occurrence of Muslims whose souls are weak, whose hearts are easily attracted to marrying bitches who expect wealth and pleasures of life. Strictly speaking, the verse does not show that marriage between a male fornicator and a pious woman is illegitimate, so is the marriage between a man who does not commit fornication and a female fornicator (AshShiddieqy, 2000: 2788) .

However, on the other hand, the judge's provision practically allows underage marriage due to extramarital relationship. Those who are willing to get married, but the age has not reached the minimum age of consent for marriage according to the Marriage Law will have reason to have an extramarital relationship or even actually do the relationship so that they can be married.

In the same way, the hadith of Prophet Muhammad as narrated by Abdullah bin Mas'ud, the Messenger of Allah said: "O young people! Anyone of you who has been able to (have physical and mental readiness) get married, then marry, as the marriage can turn down to eye gaze and keep your lust away. For those who are unable to, then fast because fasting is like castration for him”. (Muttafaq 'Alaih).

The judges' consideration also refers to the Islamic legal maxims, avoiding harms or damages is prioritized over attracting interest. Here, harms must be eliminated as they allow restrictions.

Marriage is highly recommended in Islam for someone who is physically and psychologically well-established and mature, so that it will bring benefit in the household. Such recommendation aims at 
minimizing harms because every human being is basically not allowed to bring harms against themselves or others. In principle, any harms are to avoid as much as possible, but avoiding them does not necessarily lead to other harms, either mild or even more severe ones. However, if the harms are unavoidable and inevitable except by causing other harms, then choosing a relatively lighter harm than what has happened is better.

According to the judge's perception, if marriage does not happen, it will bring more sin or more harm and become a disgrace to the community. In addition, underhanded marriage which will disrupt the legal processes that will occur in the next phase or disrupt the legal rights of the child born according to the law. Marriage is often considered as an alternative to solve social problems that will occur, such as marrying off a pregnant daughter to avoid disgrace among the community and children who have had intimate relationships. Here, if they are not married, the community will see it negatively. A woman who is pregnant without husbands, for instance, would be insulted and ostracized by the community. This can lead the woman to be isolated and be selfish. This can also happen to children who will be born.

\section{Conclusion}

In urban areas, the dominant factor behind the application for marriage dispensation at the Religious Court of South Jakarta is extramarital pregnancy. This is found under the Provision of marriage dispensation Number: 056/Pdt.P/2010/ PA.JS., Provision Number: 219/Pdt.P/2011/PA.JS and Provision Number: 197/ Pdt.P/2011/PA.JS. Three cases of marriage dispensation are all granted by the Religious Court of South Jakarta on the grounds of avoiding harm and not contradicting to the legislation. This means the judge's consideration is not only based on the Marriage Law and the Compilation of Islamic Law as a legal basis in determining the decision, but also the Judge's consideration on the harms if the application for marriage dispensation is refused. In determining the consideration of the harms, the Panel of Judges are influenced by their religious views and social consequences.[] 
174 - Isnawati Rais

\section{References}

Abidin, Slamet, et. al., Fiqih Munakahat I: Untuk Fakultas Syariah Komponen $M K D K$, (Bandung: Pustaka Setia, 1999).

Adhim, Muhammad Fauzil, Indahnya Pernikahan Dini, (Jakarta: Gema Insani Press, 2002).

Al Azhar, Mudzakaroh, Tentang Perkawinan di Bawah Umur, (Jakarta: Agustus 1985).

Al Hadhrami, Salim bin Smeer, Safinatun Najah, terj. Abdul Kadir al-Jufri, (Surabaya: Mutiara Ilmu, 1994).

Al Jazairi, Abdurrahman, al-Figh 'ala al-Madzahib al-Arba'ah, (Beirut: Dar alFikr, 1990).

Ali, Zainuddin, Hukum Perdata Islam di Indonesia, (Jakarta: Sinar Grafika, 2009). Al Shahir, Muhammad Amin, Hashiyah Radd al-Mukhtar, (Beirut: Dar al-Fikr, tt.)

Arikunto, Suharsimi, Prosedur Penelitian : Suatu Pendekatan Praktek, (Jakarta: Rineka Cipta, 2002).

As'ad, Aliy, Fathul Mu’in Jilid 2, terj.Moh. Tolchah Mansor, (Kudus: Menara, t.t.). Ash Shiddieqy, Teungku Muhammad Hasbi, Tafsir al-Quranul Majid An-Nur 4, (Semarang: Pustaka Rizki Putra, 2000).

Asikin, Amirudin Zainal,Pengantar Metode Penelitian Hukum,(Jakarta: PT Rajagrapindo, 1995).

Athibi, Ukasyah, Wanita Mengapa Merosot Akhlaknya, (Jakarta: Gema Insani, 1998).

Bisri, Cik Hasan, et al., Kompilasi Hukum Islam dan Peradilan Agama dalam SistemHukum Nasional, (Jakarta: Logos Wacana Ilmu, Cetakan ke-2, 1999).

Daly, Peuhoh, Hukum Perkawinan Islam, (Jakarta: Bulan Bintang, 1988).

Departemen Agama RI., Al-Qur'an dan Terjemahnya, (Jakarta: Proyek Pengadaan KitabSuci al-Qur'an, 1984).

Departemen Pendidikan dan Kebudayaan, Kamus Besar Bahasa Indonesia, (Jakarta: Balai Pustaka, 1988).

Direktorat Jenderal Bimbingan Masyarakat Islam dan Penyelenggaraan Haji, Undang-Undang Nomor 1 Tahun 1974 Tentang Perkawinan dan Peraturan Pemerintah Nomor 9 Tahun 1975 serta Kompilasi Hukum Islam di Indonesia, (Jakarta : Departemen Agama RI, 2004).

Hoerudin, Ahrun, Pengadilan Agama, (Bandung: Citra Aditya Bakti, 1999).

Masyhur, Mustafa, Qudwah di Jalan Dakwah, terjemah oleh Ali Hasan, (Jakarta: Citra Islami Press, 1999).

Moleong, Lexy, J., Metode Penelitian Kualitatif, (Bandung: PT RemajaRosdakarya, 2004).

Mudzhar, M. Atho, et al., Hukum Keluarga di Dunia Islam Modern, (Jakarta: Ciputat Press, 2003). 
Mufidah, Psikologi Keluarga Islam Berwawasan Gender, (Malang: UIN Malang Press, 2008).

Mughniyah, Muhammad Jawad, Fiqih Lima Madzhab, (Jakarta: Penerbit Lentera, 2004).

Muhammad, Abubakar, Terjemahan Subulussalam III, (Surabaya: Al-Ikhlas, 1995).

Mujieb, M. Abdul, et. al., Kamus Istilah Fiqih, (Jakarta: Pustaka Firdaus, 1994).

Narbuko, Cholid, Abu Achmadi, Metode Penelitian,(Jakarta: Bumi Pustaka, 1997).

Nasution, S., MetodeResech, (Jakarta: Bumi Aksara, 2001).

Nazir, M., Metode Penelitian, (Jakarta: Ghalia Indonesia, 2003).

Nuruddin, Amiur, et. al., Hukum Perdata Islam di Indonesia: Studi Krisis Perkembangan Hukum Islam dari Fikih, UU No. 1/1974 sampai KHI, (Jakarta: Fajar Interpratama Offset, 2004).

Putra, Teguh Surya, Hasil Penelitian: Dispensasi Umur Perkawinan, (Malang: Fakultas Hukum Universitas Brawijaya, 2013).

Rafiq, Ahmad, Hukum Islam di Indonesia, (Jakarta: Rajawali Press, 1998).

Sabiq, Sayyid, Fiqh al-Sunnah, terj. Mahyuddin Syaf, (Bandung: PT. Al-Ma'arif, 1994).

Soekanto, Soerjono, Pengantar Penelitian Hukum,(Jakarta: UI Press, 1998).

Soekanto, Soerjono dan Abdurrahman, Metode Penelitian Hukum, (Jakarta: RinekaCipta, 2003).

Soetomo, Pengantar Hukum Tata Pemerintahan, (Malang: Universitas Brawijaya, 1981).

Subagyo, P. Joko, Metode Penelitian dalam Teori dan Praktek, (Jakarta: RinekaCipta, 1991).

Sudarsono, , Hukum Perkawinan Nasional, (Jakarta: Rineka Cipta, 2010).

Suwondo, Nani, Hukum Perkawinan dan Kependudukan di Indonesia, (Bandung: PT. Bina Cipta, 1989).

Syarifuddin, Amir, Hukum Perkawinan Islam di Indonesia, (Jakarta: Kencana, 2007).

Thalib, Sayuti, Hukum Kekeluargaan Indonesia,(Jakarta: UI Press, Cetakan ke8,1986).

Tim Disbintalad, Al-Qur'an dan Terjemah Indonesia, (Jakarta: PT. Sari Agung, 1995).

Tim Penyusun MUI, Himpunan Fatwa Majelis Ulama Indonesia, (Jakarta: MUI, 2010).

Tim Redaksi Pustaka Yustisia, Hukum Keluarga: Kumpulan Perundangan Tentang Kependudukan, Kompilasi Hukum Islam, Perkawinan, Perceraian, KDRT, dan Anak, (Yogyakarta : Pustaka Yustisia, 2010). 
176 - Isnawati Rais

Undang-undang Nomor 1 Tahun 1974 Tentang Perkawinan dan Peraturan Pemerintah Nomor 9 Tahun 1975 serta Kompilasi Hukum Islam di Indonesia, (Jakarta: Dirjen Bimas Islam Depag RI, 2004).

Usman, Husaini, Metodologi Penelitian Sosial, (Jakarta: Bumi Aksara, 2001).

'Uwaidah, Kamil Muhammad, Fiqih Wanita, (Jakarta: Pustaka Al-Kautsar, 1998).

Isnawati Rais, Lecturer at the Faculty of Sharia and Law Syarif Hidayatullah State Islamic University Jakarta. 


\section{Mhliam}

AHKAM Jurnal Ilmu Syariah (ISSN: 1412-4734/E-ISSN: 2407-8646) is a periodical scientific journal published by Faculty of Sharia and Law of Syarif Hidayatullah State Islamic University Jakarta in collaboration with Indonesian Scientist and Sharia Scholar Association (HISSI). This journal specifically examines the science of sharia and obtains to present various results of current and eminence scientific research. The administrators receive articles as contributions Sharia and Islamic law disciplines from scientists, scholars, professionals, and researchers to be published and disseminated. The article will be situated in a selection mechanism, a review of proved reders, and a strict editing process. All articles published in this Journal are based on the views of the authors, but they do not represent the authors' journals or affiliated institutions.

AHKAM has been accredited based on the determination of Director General of Research Reinforcement and Development, Research, and Technology Ministry of Higher Education of Republic of Indonesia, No. 36/a/E/KPT/2016 (valid until 2021). 